\title{
Occurrence of acanthocephalans in the Eurasian otter Lutra lutra (L.) (Carnivora, Mustelidae) in Bulgaria, with a survey of acanthocephalans recorded from this host species
}

\author{
Z. M. DIMITROVA ${ }^{1}$, Y. TZVETKOV ${ }^{2}$, I. TODEV ${ }^{2}$
}

\begin{abstract}
${ }^{1}$ Department of Biology, Faculty of Agriculture, Thracian University, Student Campus, 6000 Stara Zagora, Bulgaria, E-mail: zmd@af.uni-sz.bg; ${ }^{2}$ National Station of Game Biology and Pathology, 5 Iskarsko Shose, 1528 Sofia, Bulgaria
\end{abstract}

\begin{abstract}
Summary
Three Eurasian otters (Lutra lutra) originating from Pazardzhik Region (South Bulgaria) were examined for helminth parasites. Three species of acanthocephalans were recorded: Pomphorhynchus laevis, Acanthocephalus anguillae and $A$. ranae. These species are not specific parasites of otters, the former two occurring in various freshwater fishes and the latter being a parasite of anurans. A review of acanthocephalan species recorded from $L$. lutra is presented. The possible transmission routes by which otters become infested with acanthocephalans are considered to be either paratenic transfer of encysted extra-intestinal juveniles in paratenic hosts or postcyclic transmission of mature intestinal worms in definitive hosts.
\end{abstract}

Key words: Acanthocephala, Eurasian otter, Bulgaria

\section{Introduction}

According to the international criteria, the Eurasian otter Lutra lutra (L.) is classified as a near threatened species (IUCN, 2007). It is also of great conservational importance in Bulgaria (Popov and Sedefchev, 2003). Mostly for this reason, its helminth fauna is poorly studied. The only helminth species recorded from this host in Bulgaria is the digenean Euryhelmis squamula (Rudolphi, 1819) (see Janchev, 1987). No acanthocephalans were previously reported from Eurasian otters in this country. The aim of this article is to report on the acanthocephalans recorded in Eurasian otters from Bulgaria and to present a survey on acanthocephalans recorded from this host species throughout its geographical range.

\section{Materials and Methods}

The present study was based on acanthocephalans isolated from three road-killed Eurasian otters originating from the vicinities of the village of Yunatsite (Pazardzhik Region) in the period $1996-1999$. The data about the collection date and the number of specimens are presented in the section for each species. The specimens were fixed and preserved in $70 \%$ ethanol. They were cleared in glycerol $(25-100 \%)$ or dimethylphthalate and studied in temporary mounts. The measurements are in millimetres unless otherwise stated. Figures given in parentheses after the range are those of single measurements outside the normal range.

\section{Results}

Three species of acanthocephalans were found in the course of the present study:

Class Palaeacanthocephala Meyer, 1931

Order Echinorhynchida Southwell \& MacFie, 1925

Family Echinorhynchidae Cobbold, 1876

Acanthocephalus anguillae (Müller, 1780) Lühe, 1911

(Fig. 1. A-D)

Specimens studied: 3 females, February 1999.

Description (based on 3 females):

Trunk elongate, almost cylindrical, narrowing posteriorly; $7.60-9.52$ long and $0.93-1.24$ wide. Proboscis elongateoval, situated at angle to trunk axis; $0.73-0.76$ long and $0.28-0.34$ wide. Proboscis armament consists of $8-10$ longitudinal rows of 5 (6) hooks in each row. Hooks with well developed roots, posteriorly directed. Roots with two antero-lateral processes; only roots of some last hooks without such processes. Length of first 4 (5) hooks - blade $81-188(194) \mu \mathrm{m}$, root $53-97 \mu \mathrm{m}$, anterior processes 13 - 25 (30) $\mu \mathrm{m}$; Length of last hook - blade $33-78 \mu \mathrm{m}$, root $30-55 \mu \mathrm{m}$. Neck almost cylindrical, $0.60-0.70$ long and $0.28-0.31$ wide. 'Pseudocollum' trapezoid, $0.26-0.37$ 
long and $30-38$ wide (at anterior end) and $0.43-0.52$ wide (at posterior end). Proboscis receptacle cylindrical, double-walled, attached at proboscis base; $0.95-0.97$ long and $0.17-0.24$ wide. Lemnisci enlarged and rounded at posterior end, $0.83-1.00$ long and $0.13-0.26$ wide. Female genital tract about $0.70-1.30$ long. Vagina provided with one sphincter. Genital pore terminal. Numerous unripe eggs observed through body wall, $54-61 \mu \mathrm{m}$ long and $37-44 \mu \mathrm{m}$ wide, without polar prolongations.

Remarks:

Comparing morphometric data of the present specimens with previous descriptions (Lühe, 1911; Petrochenko, 1956; Čanković et al., 1968; Rokicki, 1970; Andryuk, 1979; Kakacheva-Avramova, 1983; Brown et al., 1986), we found some differences. The longitudinal rows of hooks in our material range from 8 to 10 , while according to the mentioned above authors, the number of longitudinal rows is ten. The maximum dimensions of the hooks of the present specimens are most similar to specimens from Poland, $198 \mu \mathrm{m}$ (Rokicki, 1970) vs $194 \mu \mathrm{m}$ in Bulgarian material. Petrochenko (1956) and Lühe (1911) recorded smaller dimensions of hooks, $136 \mu \mathrm{m}$ and $140 \mu \mathrm{m}$ (the latter taken from the drawing), respectively. The description by Kakacheva-Avramova (1983) was based mostly on male specimens and dimensions of the hooks of female specimens are presented as 'greater than those of the male specimens' (i.e., more than $97 \mu \mathrm{m}$ ).
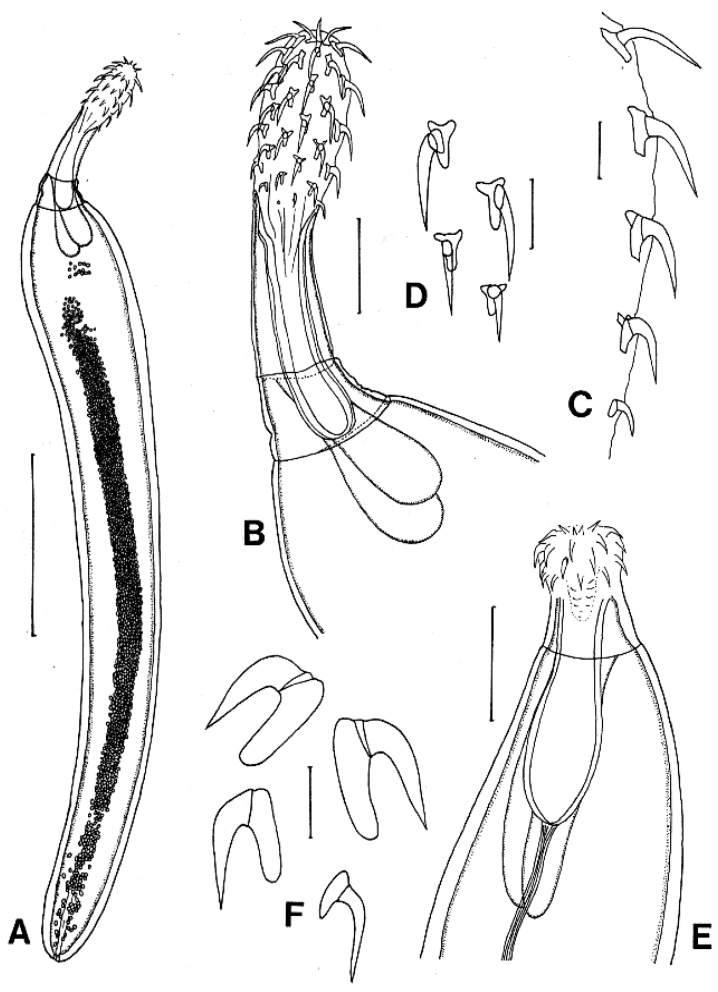

Fig. 1. Acanthocephalus ssp. A - D: A. anguillae (Müller, 1780), Females: A - General view; B - Proboscis and anterior part of trunk; C - Longitudinal row of hooks (lateral view); D - Hooks, frontal view. E - F: A ranae (Schrank, 1788), Female: E - Proboscis and anterior part of trunk; F - Last two hooks in two adjacent rows (lateral view). Scale-bars = $2.0 \mathrm{~mm}(\mathrm{~A}) ; 0.4 \mathrm{~mm}(\mathrm{~B}, \mathrm{E}) ; 0.1 \mathrm{~mm}(\mathrm{C}, \mathrm{D}) ; 0.05 \mathrm{~mm}(\mathrm{~F})$
The specimens studied possess a 'pseudocollum' posteriorly to the neck (Figure $1 \mathrm{~A}, \mathrm{~B}$ ). Achmerov and Dombrowskaja-Achmerova (1941) erected the genus Paracanthocephalus for species with a pseudocollum. Some authors (Yamaguti, 1963; Amin, 1985, Golvan, 1994) considered this genus as a synonym of Acanthocephalus Koelreuther, 1771. Kakacheva-Avramova (1983) recorded Paracanthocephalus tenuirostris Achmerov \& Dombrowskaja-Achmerova, 1941 from Bulgaria. The proboscis armament of the Bulgarian materials consists of 6 or $7-8$ longitudinal rows, 5 or $5-6$ hooks in row, with maximum length of hooks $98-117 \mu \mathrm{m}$ and length of eggs are $83-117$ $\mu \mathrm{m}$ (Kakacheva-Avramova, 1983) vs 6 longitudinal rows, 5 hooks in row, maximum length of hooks $119 \mu \mathrm{m}$ and length of eggs $40-41 \mu \mathrm{m}$ in materials from the Russian Far East (Achmerov and Dombrowskaja-Achmerova, 1941; Achmerov, 1959). Furthermore, the material of Kakacheva-Avramova (1983) corresponds to some characters of Paracanthocephalus rauschi Schmidt, 1969 from Alaska (6 - 8 longitudinal rows, $5-6$ hooks in row, maximum length of hooks $-130-167 \mu \mathrm{m}$ and length of eggs are 65 $-88 \mu \mathrm{m})$ (Schmidt, 1969). The present female specimens possess a pseudocollum but strongly resemble $A$. anguillae in the remaining characters, thus supporting the synonymy of the genera Acanthocephalus and Paracanthocephalus. A. anguillae has been recorded from Salmo trutta fario L., Esox lucius L., Leuciscus cephalus (L.), L. idus (L.), Blicca bjoerkna (L.), Rutilus rutilus (L.), Alburnus alburnus (L.), Barbus meridionalis Risso and B. cyclolepis Heckel (=B. tauricus cyclolepis Heckel) in Bulgaria (Kakacheva-Avramova, 1983; Kirin, 2000; 2001a; 2001b; 2002a; 2002b; 2002c; 2003c; Kirin et al., 2003; 2005). The occurrence of $A$. anguillae in the Eurasian otter is a new host record in Bulgaria. Previously, A. anguillae was reported from $L$. lutra in Sweden (Lundström, 1942), Germany (former DDR) and Austria (Reitter, 2001) (Table 1).

Acanthocephalus ranae (Schrank, 1788) Lühe, 1911 (Fig. 1. E-F)

Specimens studied: 1 female, April 1996.

Description - female:

Trunk elongate, cylindrical, narrowing posteriorly; 13.40 long and 0.92 wide. Numerous fragments of hypodermal nuclei observed. Proboscis about 0.50 long (partly invaginated) and 0.28 wide. Proboscis armament consists of 16 longitudinal rows, 2 hooks in each row (the anterior $3-4$ hooks invaginated and are probably 4 th -5 th or 5 th -6 th hooks. Hooks with well-developed roots, posteriorly directed. In every second row, last hook is smaller, with shorter root. Length of anterior hooks: blade $78-88 \mu \mathrm{m}$, root $64-83 \mu \mathrm{m}$. Length of posterior hooks: blade $83-86$ $\mu \mathrm{m}$ and root $62-66 \mu \mathrm{m}$, or blade $52-64 \mu \mathrm{m}$ and root 29 - $39 \mu \mathrm{m}$. Neck trapezoid, 0.23 long, 0.26 wide (at anterior end) and 0.35 wide (at posterior end). Proboscis receptacle sacciform, double-walled, attached at proboscis base; 0.86 long and 0.26 wide. Lemnisci 1.00 long and 0.15 wide. Female genital tract about 1.20 long. Vagina provided with one sphincter. Genital pore terminal. Numerous unripe 
eggs (without polar prolongations) observed through body wall, $56-81 \mu \mathrm{m}$ long and $29-39$ (66) $\mu \mathrm{m}$ wide.

Remarks:

Comparing morphometric data of the present specimen with previous descriptions (Lühe, 1911; Petrochenko, 1956; Grabda-Kazubska, 1962, Golvan, 1969), we find a greater maximum length of hooks $(86-88 \mu \mathrm{m})$ in comparison with the data $(70-71 \mu \mathrm{m})$ of Lühe (1911), Petrochenko (1956) and Golvan (1969). In relation to this character, our material is more similar to the specimens from Poland and Bulgaria - $91-95 \mu \mathrm{m}$ and $80-85 \mu \mathrm{m}$, respectively (Grabda-Kazubska, 1962; Dimitrova, 1998).

Previously, this species was recorded from Bombina variegata (L.), Bufo viridis Laurenti, Hyla arborea (L.), Rana ridibunda Pallas, $R$. esculenta L., $R$. temporaria L., $R$. dalmatina Fitzinger in Bonaparte and R. graeca Boulenger in Bulgaria (Bachvarov, 1977; 1982a; 1982b; 1983; 1984; Bachvarov and Petrov, 1978; Kirin, 2003a; 2003b). Dimitrova et al. (2000) recorded this species from Larus argentatus Pontoppidan in Bulgaria. The finding of $A$. ranae in the otter is a new host record for Bulgaria. The other record of A. ranae in L. lutra is from Romania (Chiriac and Barbu, 1968, see Table 1).

Family Pomphorhynchidae Yamaguti, 1939

Pomphorhynchus laevis (Zoega in Müller, 1776) Van Cleave, 1924 (Fig. 2)

Specimens studied: 1 male, 1 female and 1 metasoma juveniles, February 1999; 1 adult female, March 1999.

Description (based on 2 juvenile specimens), February 1999:

Male. Trunk 2.22 long and 0.93 wide. Proboscis cylindrical, 0.53 long ( 0.34 evaginated and 0.19 invaginated), 0.23 wide at base. Proboscis armament consists of 17 longitudinal rows, $6-7$ hooks in each row (anterior $3-4$ hooks invaginated). Hooks with well-developed roots, posteriorly directed. Length of hooks: blade $35-50 \mu \mathrm{m}$, root $22-49$ $\mu \mathrm{m}$. Neck cylindrical, 1.40 long and 0.40 wide; anterior part of neck transformed into bulb, 0.40 long and 0.36 wide. Proboscis receptacle double-walled, attached at proboscis base, 1.23 long and 0.11 wide. Lemnisci cannot be measured. Testes oval, situated in tandem, $0.23-0.28$ long and $0.15-0.18$ wide. Cement glands and ducts not distinct.

Female. Trunk 3.00 long and 1.30 wide. Proboscis cylindrical, 0.62 long and 0.20 wide. Proboscis armament consists of 17 longitudinal rows, $10-11$ hooks in each row. First 8 hooks with well-developed roots, posteriorly directed. Roots of next two hooks also directed posteriorly, but possess small apophyses $(5-7 \mu \mathrm{m}$ long); most posterior hooks with root directed anteriorly. Length of first 5 hooks: blade $47-54 \mu \mathrm{m}$, root $40-59 \mu \mathrm{m}$; length of next 5 hooks: blade $40-48 \mu \mathrm{m}$, root $27-47 \mu \mathrm{m}$; length of last hooks: blade $37 \mu \mathrm{m}$, root $27 \mu \mathrm{m}$. Neck cylindrical, 1.80 long and 0.44 wide; anterior part of neck transformed into bulb, 0.80 long and 0.65 wide. Proboscis receptacle double-walled, attached at proboscis base, 1.32 long and
0.19 wide. Lemnisci deformed, about 1.0 long. Vagina provided with one sphincter. Genital pore terminal.

Additional data (based on one adult female, March 1999): Trunk 9.3 long and 1.9 wide. Proboscis about 0.50 long (the remaining part invaginated in a bulb). Proboscis armament consists of 18 longitudinal rows, $7-8$ hooks in row (remaining hooks invaginated in a bulb). Length of anterior $3-4$ hooks: blade $50-53 \mu \mathrm{m}$, root cannot be measured. Neck 2.40 long and 0.68 wide; anterior part of neck and bulb deformed. Female genital tract about 2.40

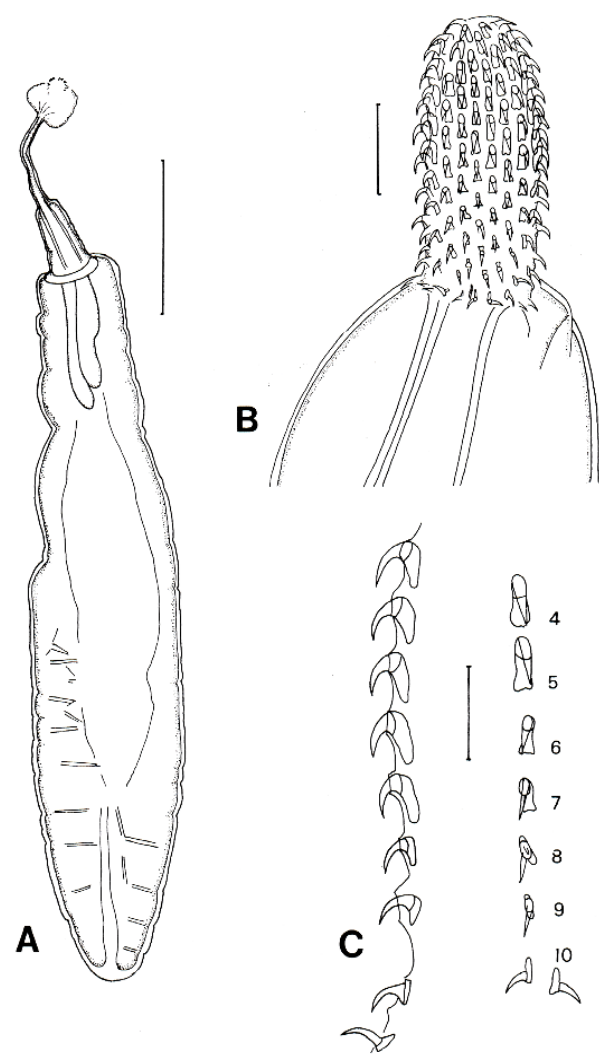

Fig. 2. Pomphorhynchus laevis (Zoega in Müller, 1776), Females: A - General view of adult specimen; B - Proboscis and part of bulb of juvenile specimen; $\mathrm{C}$ - Longitudinal rows of hooks (left - lateral view, right - frontal view). Scale - bars $=2.0 \mathrm{~mm}(\mathrm{~A}) ; 0.2 \mathrm{~mm}(\mathrm{~B})$; $0.1 \mathrm{~mm}(\mathrm{C})$

long. Numerous ovarian balls seen through body wall. Remarks:

The present specimens have a shorter proboscis, $0.53-$ $0.62 \mathrm{~mm}$ versus $0.70-0.90 \mathrm{~mm}$ (Kostylev, 1928, cited after Petrochenko, 1956; Meyer, 1933; Petrochenko, 1956; Čanković et al., 1968; Brown et al., 1986) and are comparable with the minimum dimensions of the proboscis presented by Lühe (1911), i.e. 0.60 - 1.00, and KakachevaAvramova (1983), i.e. 0.49 - 1.50. Another difference concerns the armature of the proboscis, i.e. $17-18$ longitudinal rows, $10-11$ hooks in each row in specimens studied vs 18-21, 11-13 hooks per row (Lühe, 1911; Kostylev, 1928, cited after Petrochenko, 1956; Meyer, 1933; Petrochenko, 1956; Čanković et al., 1968; Kakacheva-Avra- 
mova, 1983). On the basis of this character, our specimens are comparable to those from Great Britain having $13-20$ longitudinal rows, $8-13$ hooks in each row (Brown et al., 1986). In addition, the maximum dimensions of the hook blades are greater $(47-54 ; 40-48 ; 37 \mu \mathrm{m}$, respectively), since previous authors (Kostylev, 1928, cited after Petrochenko, 1956; Petrochenko, 1956; Čanković et al., 1968) reported $48-50,33-40$ and $19-20 \mu \mathrm{m}$, respectively, for this character. Kakacheva-Avramova (1983) only reported longer blades of the last hooks $(48 \mu \mathrm{m})$.

In Bulgaria, $P$. laevis was recorded from about 50 freshwater fish species (Kakacheva-Avramova, 1983; Kirin, 2000; 2001b; 2006; Kirin et al., 2005). In 12 of these hosts (mainly of the family Gobiidae), the acanthocephalans were found as encysted juveniles in the intestinal wall, body cavity, liver and gall-bladder (Margaritov, 1966; Kakacheva-Avramova, 1972, 1973, 1977). Encysted juveniles of this species were also found in Rana ridibunda (wall of the small intestines, gall-bladder) from North Bulgaria (Bachvarov et al. 1976). The finding of $P$. laevis in the otter is a new host record in Bulgaria. Reitter (2001) recorded this species from L. lutra in Germany and Austria (Table 1).
(2) infestation with encysted juveniles by eating paratenic hosts (paratenic transmission), and (3) infestation with adult parasites by eating definitive hosts (postcyclic transmission). The diet of the otter consists of fish, frogs, crabs, insects, aquatic birds and some rodents (Fairley, 1972; Fairley and Wilson, 1972; Machida, 1973; Görner and Hachethal, 1987; Macdonald and Barrett, 1993; Popov and Sedefchev, 2003; Georgiev, 2006). The acanthocephalans recorded from Eurasian otters (Table 1) have as intermediate hosts amphipods, isopods and terrestrial insects. Therefore, the infection route involving cystacanths from intermediate hosts seems less possible.

Corynosoma strumosum occurs in the intestine of seals, sometimes in mustelid mammals and aquatic birds; its intermediate hosts are amphipods (Petrochenko, 1958; Khokhlova, 1986). As paratenic hosts, numerous marine and freshwater fishes are known (Petrochenko, 1958; Schmidt, 1985). Infrequently, grass snakes (Sharpilo, 1976; Khokhlova, 1986), insectivores and mustelids (Prokopič and Genov, 1974; Shimalov and Shimalov, 2001) were reported as its paratenic hosts. C. strumosum was found in Eurasian otters in coastal habitats of British Islands (Jefferies et al., 1990; Weber, 1991; McCarthy and

Table 1. Acanthocephalan species reported from Lutra lutra (L.)

\begin{tabular}{|c|c|c|}
\hline Acanthocephalan species & Localities & References \\
\hline \multicolumn{3}{|l|}{ Family Moniliformidae Van Cleave, 1924} \\
\hline Moniliformis moniliformis (Bremser, 1811) & Caucasus & $\begin{array}{l}\text { Butzeck (1984, cited after Torres } \\
\text { et al., 2004) }\end{array}$ \\
\hline Moniliformis sp. (= Gigantorhynchus sp.) & Spain & Torres et al. (2004) \\
\hline \multicolumn{3}{|l|}{ Family Arhythmacanthidae Yamaguti, 1935} \\
\hline Heterosentis plotosi Yamaguti, 1935 & Japan & Machida (1973) \\
\hline \multicolumn{3}{|l|}{ Family Echinorhynchidae Cobbold, 1876} \\
\hline \multirow[t]{2}{*}{ Acanthocephalus anguillae (Müller, 1780) } & Sweden & Lundström (1942) \\
\hline & Germany and Austria & Reitter (2001) \\
\hline \multirow[t]{2}{*}{ A. lucii (Müller, 1776) } & Sweden & Lundström (1942) \\
\hline & Germany and Austria & Reitter (2001) \\
\hline Acanthocephalus sp. (= A. cf. ranae Schrank, 1788) & Romania & Chiriac and Barbu (1968) \\
\hline Acanthocephalus sp. & Ireland & Fairley (1972) \\
\hline Acanthocephalus sp & Russia (Sakhalin) & Ben’kovskiy et al. (1973) \\
\hline Acanthocephalus sp. & Germany and Austria & Reitter (2001) \\
\hline Echinorhynchus sp. & Britain (coastal sites) & Jefferies et al. (1990) \\
\hline Pseudoacanthocephalus sp. & Latvia & Vismanis and Ozolins (1998) \\
\hline \multicolumn{3}{|l|}{ Family Pomphorhynchidae Yamaguti, 1939} \\
\hline Pomphorhynchus laevis (Zoega in Müller, 1776) & Germany and Austria & Reitter (2001) \\
\hline \multicolumn{3}{|l|}{ Family Polymorphidae Meyer, 1931} \\
\hline \multirow[t]{3}{*}{ Corynosoma strumosum (Rudolphi, 1802) } & Britain (coastal sites) & Jefferies et al. (1990) \\
\hline & Shetland & Weber (1991) \\
\hline & Ireland & McCarthy and Hassett (1993) \\
\hline Polymorphus minutus (Goeze, 1782) & Germany and Austria & Reitter (2001) \\
\hline
\end{tabular}

\section{Discussion}

Eight acanthocephalan species were reported from L. lutra (Table 1) and none of them being its specific parasite. Three possible infection routes can be considered: (1) infestation with cystacanths by ingesting intermediate hosts,
Hassett, 1993) and it is likely that various fishes had a role in the transmission acting as paratenic hosts: Gadus morhua L. (see Jefferies et al., 1990), Zoarces viviparus (L.) and Cyclopterus lumpus L. (Weber, 1991).

Another transmission route can be associated with predation on definitive hosts. Bozhkov $(1969,1982)$ defined as 
postcyclic parasitism the transmission of mature individuals from a definitive host to another host through predation or cannibalism. The experimental postcyclic transmission of adult intestinal worms was proved for 11 acanthocephalan species (Nickol, 2003; McCormick and Nickol, 2004). Since the postcyclic transmission is frequent in acanthocephalans, it better explains the occurrence of the remaining species in Eurasian otters (Table 1).

Moniliformis moniliformis (= M. dubius Meyer, 1932) is mainly a parasite of rodents, rarely of carnivores and insectivores (Khokhlova, 1986). Its intermediate hosts are insects belonging to the Blattidae, Tenebrionidae and Scarabaeidae (Moore, 1946; Schmidt, 1985; Khokhlova, 1986). Toads are known as experimental (Moore, 1946) and lizards as natural paratenic hosts (Sharpilo, 1976). However, these paratenic hosts were considered 'traps' for the cystacanths of this species (Sharpilo, 1979; Sharpilo et al., 1996). Therefore, the infection in L. lutra seems more likely to originate from infected rodents.

Heterosentis plotosi is a parasite of the shore fish Plotosus lineatus (Thunberg); its intermediate and paratenic hosts are unknown (Golvan, 1969; Schmidt, 1985). Machida (1973) considered its occurrence in the intestine of L. lutra whiteleyi Grey as 'accidental infection' due to its prey consisting mostly of shore fishes. Essentially, this infection is to be considered a result of postcyclic transmission of adult worms.

Acanthocephalus anguillae is an intestinal parasite of freshwater fishes, with isopods as intermediate hosts (Schmidt, 1985). Though it can be found in extra-intestinal sites, its life cycle is not dependent on paratenic hosts (Taraschewski, 2000). Adult specimens of $A$. anguillae were found in otters in Sweden (Lundström, 1942), Germany and Austria (Reitters, 2001), probably due to postcyclic transmission.

A. lucii is a parasite of freshwater fishes, with isopods as intermediate hosts (Schmidt, 1985). Extra-intestinal localization of this species is not known (Taraschewski, 2000). Lundström (1942) recorded 28 adult specimens from one otter in Sweden. Reitter (2001) reported this and other acanthocephalan species from otters in Germany and Austria as 'pseudoparasites'. These two records also seem to be cases of postcyclic parasitism. Another postcyclic record of this species is its occurrence in kingfisher, $\mathrm{Al}$ cedo atthis (L.), in Bulgaria (Dimitrova et al., 2000).

A. ranae is a parasite mainly of anurans, having isopods as intermediate hosts; paratenic hosts are not known (Schmidt, 1985). Chiriac and Barbu (1968) recorded 10 specimens in bad condition from the intestine of an otter and identified them as 'A. cf. ranae'. Bozhkov (1980) studied experimentaly the success of the postcyclic transmission of $A$. ranae from Rana ridibunda to Bufo viridis. There are several further records of adults of $A$. ranae in Natrix natrix (L.) in Ukraine and Belarus (Sharpilo, 1976; Shimalov and Shimalov, 2000), Vipera berus (L.) in Poland (Lewin and Grabda-Kazubska, 1997) and Larus argentatus in Bulgaria (Dimitrova et al., 2000). All these cases may represent postcyclic parasitism.
Polymorphus minutus is a parasite of aquatic birds, with amphipod intermediate hosts; paratenic hosts are unknown (Schmidt, 1985). The record of P. minutus in otters (Reitter 2001) seems to be a result of postcyclic transmission. Aquatic birds were reported as prey of otters by several studies (Fairley, 1972; Görner and Hachethal, 1987; Macdonald and Barrett, 1993; Georgiev, 2006).

$P$. laevis is a widespread intestinal parasite of freshwater fishes, with amphipod intermediate hosts (Schmidt, 1985). It is also known from extra-intestinal sites (Taraschewski, 2000). Various fishes (Margaritov, 1966; Čanković et al., 1968; Kakacheva-Avramova, 1972, 1973, 1977) and frogs (Rana ridibunda) (Bachvarov et al., 1976) were recorded as paratenic hosts. However, its ability for postcyclic transmission was experimentally proved (Kennedy, 1999). Therefore, both transmission routes (paratenic and postcyclic) seem possible in relation to this species.

On the basis of data presented above, we consider the specimens of $A$. anguillae and $A$. ranae found by us in the intestine of the otters as a probable result of postcyclic transmission from their definite hosts (fishes and frogs, respectively). Therefore, L. lutra ought to be regarded as a postcyclic host of these acanthocephalans. In relation to $P$. laevis, both postcyclic and paratenic transmission routes seem possible.

\section{References}

ACHMEROV, A. K. (1959): Fish acanthocephalans of the Amur River. Tr. GELAN, 9: 23 - 44

ACHMEROV, A. K., DOMBrowsKajA-ACHMEROVA, O. S. (1941): New Acanthocephala in fishes of the Amur River. Dokl. Akad. Nauk USSR, 31: 517 - 520

Amin, O. (1985): Classification. In CROMPTON, D. W. T. and NiCKOL, B. B. (Eds): Biology of the Acanthocephala. Cambridge University Press, Cambridge

ANDRYUK, L.V. (1979): The life cycle of Acanthocephalus anguillae. Zool. Zh., 58: $168-174$

BACHVAROV, G. (1977): Catalogue of the amphibian helminths in Bulgaria. Plovdiv Univ. "P. Khilendarski”, Plovdiv

Bachvarov, G. (1982a): Contribution to the knowledge of helminth fauna of anuran amphibians (Anura - Ecaudata) in North-West Bulgaria. Nauch. Tr. Plovdiv. Univ. "P. Khilendarski”, Biol., 20: 239 - 254

Bachvarov, G. (1982b): Contribution to the knowledge of helminth fauna of anuran amphibians (Anura - Ecaudata) from the middle part of West Bulgaria. Nauch. Tr. Plovdiv. Univ. "P. Khilendarski”, Biol., 20: 255 - 270

BACHVAROV, G. (1983): Contribution to the knowledge of helminth fauna of anuran amphibians (Anura - Ecaudata) from the Struma Valley. Nauch. Tr. Plovdiv. Univ. "P. Khilendarski”, Biol., 21: 373 - 380

BACHVAROV, G. (1984): Contribution to the knowledge of helminth fauna of anuran amphibians (Amphibia - Anura) class Nematoda and class Acanthocephala from South-East Bulgaria (Part II). Nauch. Tr. Plovdiv. Univ. "P. Khilendarski”, Biol., 22: 125 - 130 
Bachvarov, G., Chochev, B., Petrov, P. (1976): Contribution to the knowledge of helminth fauna of anuran amphibians (Anura - Ecaudata) from North Bulgaria. Nauch. Tr. Plovdiv. Univ. "P. Khilendarski", Biol., 14: 29-39

Bachvarov, G., Petrov, P. (1978): Contribution to the knowledge of helminth fauna of anuran amphibians (Anura - Ecaudata) from the Sredna Gora Mountains. Nauch. Tr. Plovdiv. Univ. "P. Khilendarski", Biol., 16: $251-260$

Ben'Kovskiy, L. M., Golovina, T. I., TCherbina, R. D. (1973): On the problem of studying the diseases and parasites of the otter in the Sakhalin Island. Vestn. Zool., 6: $21-24$

BozHKOV, D. (1969): Postcyclic parasitism and postcyclic hosts of helminths. Izv. Zool. Inst. Muz., 29: 183 - 189

BozHKOV, D. (1980): Experimental studies on the passage of mature helminths from Rana ridibunda Pall. to Bufo viridis Laur. Khelminthologiya, 10: $24-28$

BozHKov, K. D. (1982): Helminths. Life cycles and their evolution. Publ. House Nauka i izkustvo, Sofia

Brown, A. F., ChubB, J. C., Veltkamp, C. J. (1986): A key to the species of Acanthocephala parasitic in British freshwater fishes. J. Fish Biol., 28: 327 - 334

ČAnković, M., Delić, S., KiŠKarolJ, M., Rukavina, J. (1968): Parasitic fauna of freshwater fishes in Bosna and Herzegovina. Djela Akad. Nauka $i$ Umjetn. Bosne $i$ Hercegovine, Od. Pr. i Mat. Nauka, 33: 1 - 159

ChIRIAC, E., BARBU, P. (1968): Contribution to the knowledge of helminth fauna of mammals from family Mustelidae (ord. Carnivora) in Romania. St. si Cerc. Biol., Ser. Zool., 20: 273 - 281

Dimitrova, Z. M. (1998): Avian acanthocephalans in Bulgaria: morphological, taxonomic and faunistic investigations. PhD Thesis. Thracian University, Stara Zagora Dimitrova, Z., Georgiev, B.B., Genov, T. (2000): Review of the avian acanthocephalans from Bulgaria. Acta Zool. Bulg., 52: $3-22$

FAIRLEY, J. S. (1972): Food of otters (Lutra lutra) from Co. Galway, Ireland, and notes on other aspects of their biology. J. Zool., 166: $469-474$

FAIRlEY, J. S., Wilson, S. C. (1972): Autumn food of otters (Lutra lutra) on the Agivey River, County Londonderry, Northern Ireland. J. Zool., 166: 468 - 469

GeOrGIEV, D. G. (2006): Diet of the otter Lutra lutra in different habitats of South-Eastern Bulgaria. IUCN Otter Spec. Group Bull., 23: $5-11$

Golvan, Y. J. (1969): Systématique des Acanthocéphales (Acanthocephala Rudolphi, 1801). L'ordre des Palaeacanthocephala Meyer, 1931. La super-famille des Echinorhynchoidea (Cobbold, 1876) Golvan et Houin, 1963. Mem. Mus. Nat. Hist. Natur., Ser. A, Zool., 57: 1 - 373

Golvan, Y. J. (1994): Nomenclature of the Acanthocephala. Res. Rev. Parasitol., 54: 135-205

GÖRNER, M., HACHETHAL, H. (1987): Säugetiere Europas. Beobachten und bestimmen. Neumann Verlag, LeipzigRadebeul

GRABDA-KAZUBSKA, B. (1962): On the validity of the species Acanthocephalus falcatus (Frölich, 1789). Acta Parasitol. Pol., 10: 377 - 394
IUCN (2007): 2007 IUCN Red List of Threatened Species. $<$ www.iucnredlist.org $>$

JANCHEV, Y. (1987): On the morphology, taxonomy and distribution of Euryhelmis squamula (Rudolphi, 1819) (Trematoda: Heterophiidae) in some Mustelidae in Bulgaria. Khelminthologiya, 23: 50 - 58

JefFeries, D. J., HANSON, H. M., HARris, E. A. (1990): The prevalence of Pseudoterranova decipiens (Nematoda) and Corynosoma strumosum (Acanthocephala) in otters Lutra lutra from coastal sites in Britain. J. Zool., 221: 316 - 321

KAKACHEVA-Avramova, D. (1972): Contribution to the knowledge of helminth fauna of fishes from the River Tundzha. Izv. Tsentr. Khelmintol. Lab., 15: 89 - 107

KAKACHEVA-AVRAMOVA, D. (1973): Helminth fauna of fishes in the rivers from the Central and Eastern part of the Balkan Mountains. Izv. Tsentr. Khelmintol. Lab., 16: 87 - 110 KAKACHEVA-Avramova, D. (1977): Study on the helminths of fishes from the Bulgarian part of the Danube. Khelminthologiya, 3: $20-45$

KAKACHEVA-AVRAMOVA, D. (1983): Helminths of freshwater fishes in Bulgaria. Publ. House Bulg. Acad. Sci., Sofia

Kennedy, C. R. (1999): Post-cyclic transmission in Pomphorhynchus laevis (Acanthocephala). Folia Parasitol., 46: $111-116$

KHOKHLOVA, I. G. (1986): Acanthocephalans of terrestrial vertebrates from the fauna of USSR. Publ. House Nauka, Moscow

KIRIN, D. A. (2000): Ecologofaunistical study of the helminthological communities of Leuciscus cephalus L. from Maritsa River. Nauch. Tr. Sayuz Uch., Plovdiv, 1: 405 - 408 KIRIN, D. A. (2001a): Helminth parasites of Leuciscus cephalus L., 1758, and Barbus meridionalis petenyi Heckel, 1847 (Osteichthyes, Cyprinidae) from the Mesta River, Bulgaria. C. R. Acad. Bulg. Sci., 54: $101-104$

KIRIN, D. A. (2001b): Biodiversity and ecology of the helminths fauna in Leuciscus cephalus from the Maritsa River, Bulgaria. Nauch. Tr. Plovdiv. Univ. "P. Khilendarski" - Anim., 37: 79 - 84

KIRIN, D. A. (2002a): Biodiversity and ecological characteristics of the helminth communities in Barbus tauricus cyclolepis from Luda Yana River, Bulgaria. C. R. Acad. Bulg. Sci., 55: $97-102$

KIRIN, D. A. (2002b): Biodiversity and ecology of the helminth communities in Leuciscus cephalus from Arda River. C. R. Acad. Bulg. Sci., 55: $89-94$

KIRIN, D. A. (2002c): Ecological study of the intestinal helminth communities of Leuciscus cephalus (L., 1758) and appraisal of the conditions of the studied freshwater ecosystems from the Chepelarska River, Bulgaria. Acta Zool. Bulg., 54: $73-85$

KIRIN, D. A. (2003a): Biodiversity and ecological particulars of the helminth communities in Rana ridibunda Pallas, 1771 from the districts of town of Saedinenie, Bulgaria. Ex. Pathol. Parasitol., 6: $31-36$

KIRIN, D. A. (2003b): Biological diversity and ecological measurements of the helminth communities of Rana ridibunda from districts of town of Vidin. Exp. Pathol. Parasitol., 6: $37-43$ 
KIRIN, D. A. (2003c): Biodiversity and ecological evaluation of the helminth communities of Barbus cyclolepis and Alburnus alburnus from Arda River, Bulgaria. Exp. Pathol. Parasitol., 6: 44 - 50

KIRIN, D. A. (2006): Biodiversity of the helminth species and helminth communities of Esox lucius (L., 1758) from Maritsa River, Bulgaria. In Sci Papers Fac. Anim. Sci., Bucharest, The $35^{\text {th }}$ Int. Sci. Commun. Ses. Fac. Anim. Sci, Bucharest, Romania, 135 - 140

Kirin, D. A., Bachvarov, G., Kuzmanov, N., Koev, K. (2003): Biological diversity and ecological evaluation of the fresh water ecosystems from the Arda River. J. Environ. Protect. Ecol., 4: 550 - 556

Kirin, D. A., Koev, K., Ivanova, D., Kuzmanov, N. (2005): Biodiversity and ecological appraisal for conditions of the Stryama River, Bulgaria. J. Environ. Protect. Ecol., 6: 69-82

Lewin, J., GrabDA-KaZUBSKA, B. (1997): Parasites of Vipera berus L. in Poland. Acta Parasitol., 42: 92 - 96

LÜHE, M. (1911): Acanthocephalen. In BRAUER, A. (Ed.): Süsswasserfauna Deutschlands. Eine Exkursionsfauna. Gustav Fischer, Jena, 16: 1 - 116

LUNDSTRÖM, L. A. (1942): Die Acanthocephalen Schwedens, mit Ausnahme der Fischacanthocephalen von Süsswasserstandorten. C. W. Lindström, Lund

MACDONALD, D., BARRETT, P. (1993): Mammals of Britain \& Europe. Collins Field Guide. Harper Collins Publishers, London

MACHIDA, M. (1973): Heterosentis plotosi (Acanthocephala: Arhythmacanthidae) from Japanese otter. Res. Bull. Meguro Parasitol. Mus., 7: 24 - 25

MARGARITOV, N. (1966): Helminths of the digestive tract and body cavity of fishes from the Bulgarian part of the Danube. Izv. Zool. Inst. Muz., 20: 157 - 173

MCCARTHY, T. K., HASSETT, D. J. (1993): Cryptocotyle lingua (Creplin) (Digenea: Heterophyidae) and other parasites of a costal otter Lutra lutra (L.). Ir. Nat. J., 24: $280-282$

McCORMicK, A. L., NICKOL, B. (2004): Postcyclic transmission and its effect on the distribution of Paulisentis missouriensis (Acanthocephala) in the definitive host Semotilus atromaculatus. J. Parasitol., 90: 103 - 107

MeYER, A. (1933): Acanthocephala. In BronNs, H. G. (Ed.): Klassen und Ordnungen des Tierreichs. Bd. 4. Abt. 2. Buch 2. Akademische Verlagsgesellschaft M.B.H., Leipzig

Moor, D. V. (1946): Studies on the life histiry and development of Moniliformis dubius Meyer, 1933. J. Parasitol., 32: $257-271$

NiCKOL, B. (2003): Is postcyclic transmission underestimated as an epizootiological factor for acanthocephalans? Helminthologia, 40: 93 - 95

PETROCHENKO, V. I. (1956): Acanthocephalans of domestic and wild animals. Vol. 1. Publ. House Acad. Sci. USSR, Moscow
Petrochenko, V. I. (1958): Acanthocephalans of domestic and wild animals. Vol. 2. Publ. House Acad. Sci. USSR, Moscow

Popov, V., SEDEFCHEV, A. (2003): The mammals in Bulgaria. A guide. Geosoft, Sofia

PROKOPIČ, J., GENOV, T. (1974): Distribution of helminths in micromammals (Insectivora and Rodentia) under different ecological and geographical conditions. Studie $\check{C} S A V$, 9: $1-159$

REITTER, S. (2001): Untersuchungen zum Parasitenspektrum beim Fischotter (Lutra lutra Linnu 1758). $<$ http://www.arcs.ac.at/DissDB/diss/VW/trn100161>

ROKICKI, J. (1970): A contribution to the knowledge of the helminth fauna of vimba, Vimba vimba (L.), in the River Vistula. Acta Parasitol. Pol., 18: 71 - 79

SCHMIDT, G. D. (1969): Paracanthocephalus rauschi sp. n. (Acanthocephala: Paracanthocephalidae) from grayling, Thymallus arcticus (Pallas), in Alaska. Can. J. Zool., 47: $383-385$

SCHMIDT, G. D. (1985): Development and life cycles. In Crompton, D. W. T. and NickOL, B. B. (Eds): Biology of the Acanthocephala. Cambridge University Press, Cambridge SHARPILO, B. P. (1976): Parasitic worms of reptiles from the fauna of USSR. Publ. House Naukova Dumka, Kiev

ShARPILO, B. P. (1979): On the biological nature of the paratenic parasitim and its significans for the evolition of the life cycles of the helminths. Vestn. Zool., 1: $3-13$

Sharpilo, B. P., TKaCh, B. B., Lisitsina, O. I. (1996): The paratenic parasitism and 'trap host'. Mat. Yubil. Konf. UKTP, 16-17 travnya, 1995, Kiev, $111-118$

Shimalov, V. V., Shimalov, V. T. (2000): Helminth fauna of snakes (Reptilia, Serpentes) in Belorussian Polesye. Parasitol. Res., 86: 340 - 341

Shimalov, V. V., Shimalov, V. T. (2001): Helminth fauna of the American mink (Mustela vison Schreber, 1777) in Belorussian Polesie. Parasitol. Res., 87: 886 - 887

TARASCHEWSKI, H. (2000): Host-Parasite interactions in Acanthocephala: a morphological approach. Adv. Parasitol., 46: 2 - 179

TORres, J., Feliu, C., FERnÁNDEZ-MorÁN, J., RuíZOlmo, J., Rosoux, R., SAntos-Reis, M., MiQuel, J., FONS, R. (2004): Helminth parasites of the Eurasian otter Lutra lutra in southwest Europe. J. Helminthol., 78: 353 359

Vismanis, K., Ozolins, J. (1998): Preliminary data on parasites of European otter (Lutra lutra) in Latvia. Proc. VIIth International Otter Colloquium, March 14 - 19, 1998, Trebon, Czech Republic, 374 - 378

WEBER, J. - M. (1991): Gastrointestinal helminths of the otter, Lutra lutra, in Shetland. J. Zool., 224: 341 - 346

YAmaguti, S. (1963): Systema helminthum. Vol. 5. Acanthocephala. Interscience Publ., New York 